Communication

\title{
Unusual Isolated Large Clasts from the Periphery of the Lagonaki Highland, Western Caucasus: New Evidence of Classification and Origin
}

\author{
Dmitry A. Ruban \\ Department of Economics and Management, Business School, Cherepovets State University, Sovetskiy Avenue \\ 10, Cherepovets, Vologda Region 162600, Russia; ruban-d@mail.ru
}

Received: 3 November 2018; Accepted: 8 November 2018; Published: 12 November 2018

check for updates

\begin{abstract}
Large clasts are in focus of the modern geoscience research, but their broadly-accepted classification is absent and specialists tend to over-emphasize on clasts of coastal zones. New field investigations in the Western Caucasus have permitted the finding of isolated large clasts of carbonate composition that occur above the Early-Middle Jurassic shale sequence and that are covered by modern soils. These clasts can be determined either as large boulders or megaclasts (blocks) depending on the preferred classification. Their shape is chiefly irregular, although smoothened surfaces and rounded angles (resulting from previous karstification) are also registered. These large clasts are located quite far from the natural outcrops of the Late Jurassic carbonates, which are their parent rocks. The origin of these clasts can be linked to collapses of the Pleistocene cliff of a cuesta-type mountain range, which later retreated to its present position. The evidence from the study area implies the size of $1 \mathrm{~m}$ or $2 \mathrm{~m}$ as a plausible criterion for distinction of boulders and megaclasts, and it also makes claims towards the development of a wider genetic typology of megaclasts.
\end{abstract}

Keywords: cliff retreat; Jurassic; limestones; megaclast; SW Russia

\section{Introduction}

Clastic sedimentology has demonstrated significant advances during the past two decades. For instance, several classifications of large clasts $(>1 \mathrm{~m})$ were proposed by Blair and McPherson [1], Blott and Pye [2], Bruno and Ruban [3], and Terry and Goff [4]. The relevant research has focused much on large clasts occurring chiefly in coastal zones and linked genetically to hurricanes, tsunamis, and other extraordinary events in the both nearest and deep geological past [5-8]. This significant extension of the knowledge poses new questions and provokes new discussions. The two most important issues are as follows. First, the optimal and widely-accepted classification of large clasts is still missing, and its development remains an urgent task. Second, the evident emphasis on coastal clasts has distracted the research focus from many other types of clasts, including those formed because of weathering, colluvial (slope) processes, extraterrestrial impacts, etc.; as a result, the genetic knowledge of large clasts is strongly incomplete and unbalanced. To solve these problems, new field-based research in many places of the world is necessary.

The Western Caucasus in the very southwest of Russia (Figure 1) is known as a globally-representative region where numerous large clasts of different origin are abundant. This is especially true for the territory of Mountainous Adygeja where large clasts accumulate actively at the toe of steep slopes of cuesta-types mountain ranges and in river canyons. These were described comprehensively by Lubova et al. [9], and this information was used later for some classification developments and comparison with extraterrestrial objects [3]. However, new field investigations in this region have permitted the location of a portion of isolated large clasts that seem to be very unusual with regard to their origin. 
Moreover, these clasts are worth considering in tests of alternative criteria for the boundary between the size grades of boulders and megaclasts. This brief contribution addresses the noted issues and puts the regional data in the broader geological context.

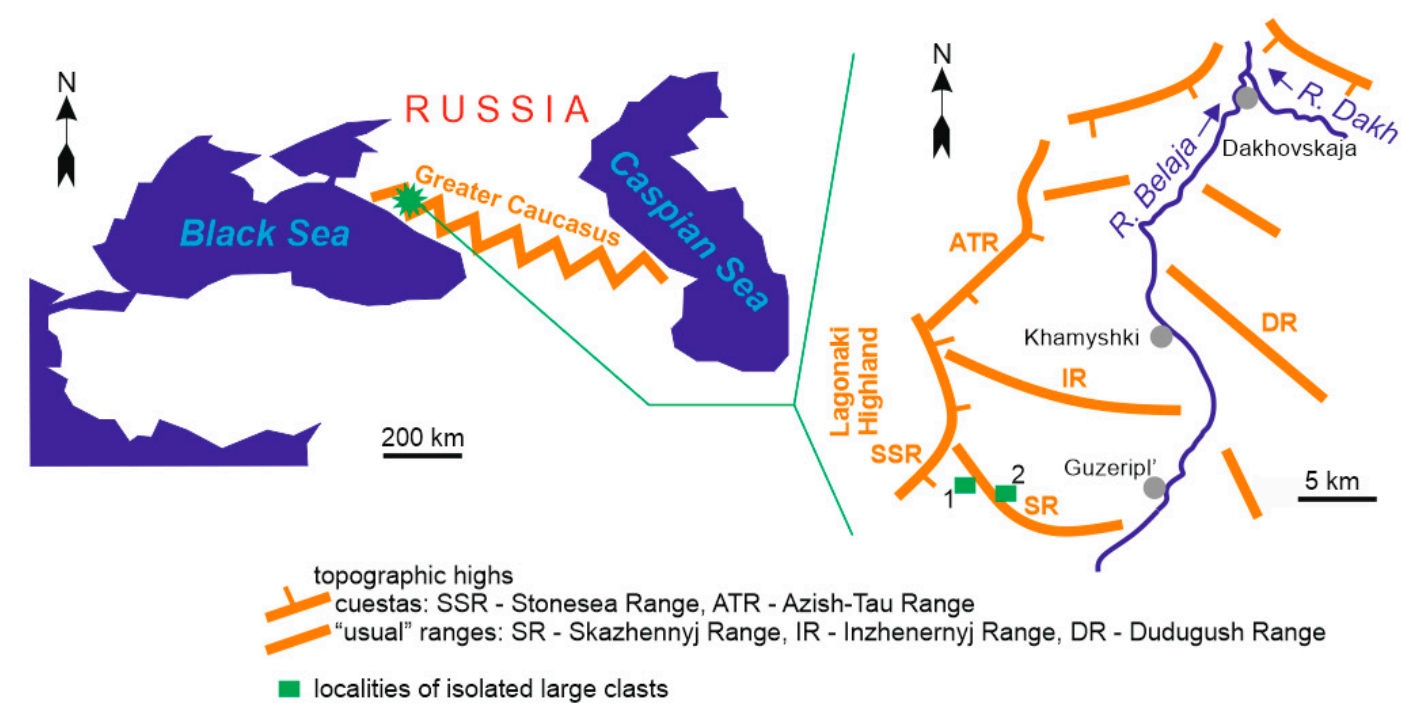

Figure 1. Location of the study area, its topographical elements, and the main large clast localities.

\section{Geographical and Geological Setting}

The Western Caucasus is a peculiar geographical and geological domain, which embraces the western edge of the Greater Caucasus Mountains (a typical Alpine-type orogen) stretching between the Black Sea and the Caspian Sea (Figure 1). The highest part of this domain with elevations $>2000-2500 \mathrm{~m}$ is distinguished as the Lagonaki Highland (often termed erroneously as a plateau) [10]. From the east and the south, this highland is bordered by the Stonesea Range, which is a typical cuesta-type range with one gentle slope and another steep, cliff-edged slope. Formation of such mountain ranges is linked to the erosion of slightly-inclined layers (almost classical monocline) of hard carbonate rocks (limestone and dolostones) overlying much softer shales with the consequent cliff retreat to the direction of layers dipping. Erosion of the underlying shales also contributes to the retreat because it undermines stability of the overlying carbonate packages. There are some other ranges of this type on the study area, and all of them belong to the lengthy and highly-complex mountain system known generally as the Skalistyj Range. However, there are also "usual" ranges with equally-shaped and somewhat irregular slopes that were formed in the shale-dominated domain of the study area (Figure 1).

Geologically, the Western Caucasus is a part of the elongated fold-thrust belt that was formed in the late Cenozoic; it evolved earlier (Mesozoic-early Cenozoic) as a back-arc basin of the Neo-Tethys Ocean [11-13]. The study area is dominated by Jurassic complexes that consist of the shale-dominated lower package with a total thickness of up to 10,000 $\mathrm{m}$ (Early-Middle Jurassic in age) and the carbonate-dominated upper package with a total thickness of up to $3000 \mathrm{~m}$ (Late Jurassic in age) [14]. Rocks of other ages, as well as small Late Paleozoic granite intrusions, also crop out locally. The Lagonaki Highland itself represents the area of maximum distribution of the upper package, whereas the outer peripheries of the highland represent the lower package. One of the most distinctive features of the highland is karst, which occurs as both endokarst (caves) and epikarst (karren and larger forms) [10,15]. Karst development is linked to the presence of Late Jurassic limestones and dolostones and heavy annual rainfall. Vegetation (especially lichens) also contributes to karstification. Various slope processes are very common on the study area, and these include rockfalls (chiefly in carbonate and granite domains, especially along collapsing cuesta cliffs and in canyons and gorges), and landslides (chiefly in shale-dominated domains). 


\section{Methods}

Isolated large clasts are reported here and there along the road linking the town of Guzeripl' in the east and the famous tourist attractions, namely the Yavorova Glade and the Partisan Glade located directly at the toe of the Stonesea Range. Two localities are judged as most representative, and clasts found there are addressed with attention (Figure 1).

Large clasts are described with regard to their size, shape, and geological context. Most important is their correct naming because of the absence of a uniform classification scheme. The size gradations proposed earlier by Blair and McPherson [1], Blott and Pye [2], Bruno and Ruban [3], and Terry and Goff [4] are all used for this purpose. The boundary between the size grades of boulders and larger clasts (commonly termed as megaclasts) corresponds to $4 \mathrm{~m} \mathrm{[1,4],2} \mathrm{m}$ [2], or $1 \mathrm{~m}$ [3]. The smallest megaclasts are termed as blocks [1,3] or mesoboulders [4]. The largest clasts below the noted boundary are large boulders (sometimes, large boulders are distinguished from very large boulders [2]). The shape of clasts is described with some criteria specified by Blott and Pye [16].

Determination of composition of large clasts is also important. Their lithology can be compared to the types of rocks known locally in order to judge about the parent rocks and the transportation routes and processes.

\section{Results}

Isolated large clasts are visible in the roadcuts. The old forest road crossing the Skazhennyj Range was improved in the beginning of the 2010s, and new road construction is being undertaken at the time of writing. As a result, lengthy artificial outcrops have appeared. These represent the Early-Middle Jurassic shales with rare sandstone and siltstone interbeds and abundant siderite concretions. The dark-grey (somewhere black) color of shales indicates high $\mathrm{C}_{\text {org }}$ content because of the deposition in oxygen-depleted conditions, where this interpretation is confirmed via trace fossil analysis [17]. Shale-dominated packages are strongly folded and faulted. These tectonic deformations took place partly in the Jurassic (Cimmerian orogeny) and partly in the late Cenozoic (Alpine orogeny). Shales are overlain by a thin $(\approx 0.5 \mathrm{~m}$ and less) layer of modern soils. Large clasts tend to occur in this layer. Because of road-improvement procedures, some clasts lost their stable position and slid down the slope of the roadcut. Hypothetically, there are many other isolated large clasts on the slopes of the Skazhennyj Range, but these remain covered by soil and vegetation. These would only be found in the case of a special survey or additional road construction.

The Locality 1 is situated directly on the Yavorova Glade (Figure 1). Two large clasts are found there (Figure 2). One clast occupies a position directly on the slope being slid from the top of the outcrop. Its size reaches $1.5 \mathrm{~m}$, which means this is a large boulder according to the classifications of Blair and McPherson [1], Blott and Pye [2], and Terry and Goff [4] or a megaclast (block) following the classification of Bruno and Ruban [3]. The shape is irregular. However, smoothened surfaces and slightly rounded angles are visible in places. Lithologically, this clast represents the Late Jurassic carbonates that are typical for the Lagonaki Highland and, particularly, the Stonesea Range. Joints and carbonate layering is visible in this clast. Another clast lies at the toe of the slope. Despite its smaller size $(\approx 1.2 \mathrm{~m})$, it shares all characteristics with the other clast described above. However, there are two distinctions. First, the shape of the second clast is flat. Second, surface smoothening and angle roundness are more evident in this case. 


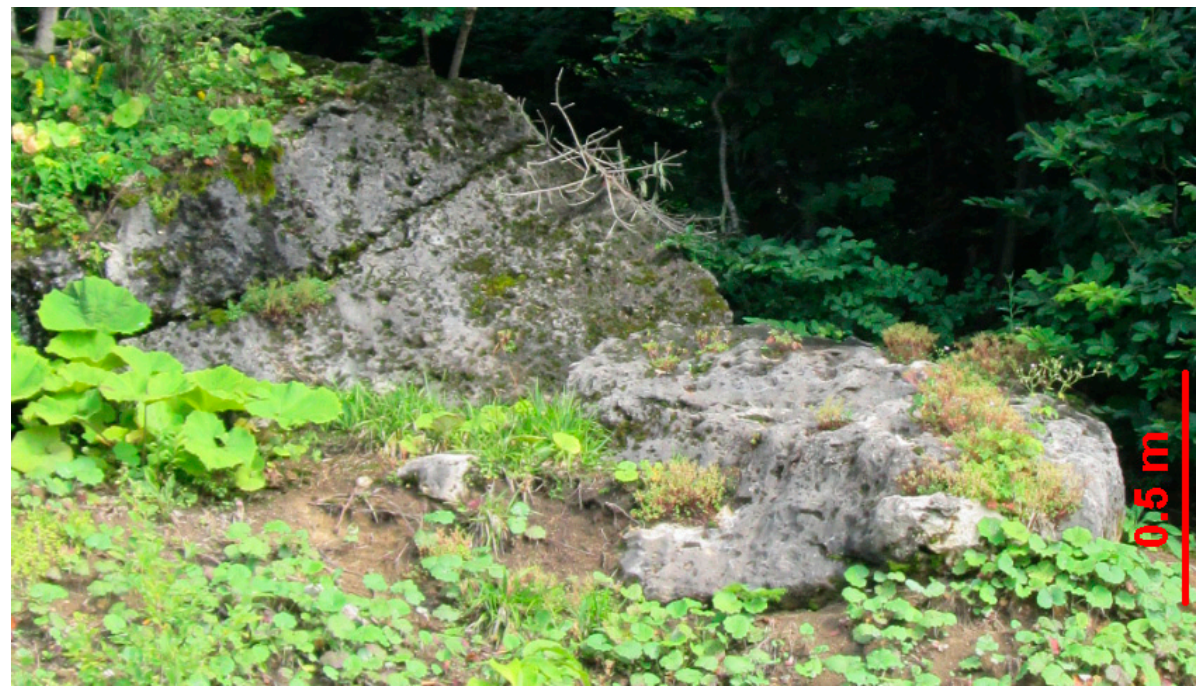

Figure 2. Large clasts of Locality 1.

The Locality 2 is situated on the other slope of the Skazhennyj Range (Figure 2) near to where the road crosses this range. Three large clasts are found there (Figure 3). One of them, the largest, occupies a natural position above the shales being almost completely covered by soil. It is slightly embedded into soft shales at the bottom. Its size exceeds $2 \mathrm{~m}$, which means this is a large boulder according to the classifications of Blair and McPherson [1] and Terry and Goff [4] or a megaclast according to the classification of Blott and Pye [2] and Bruno and Ruban [3]. The shape is irregular, but the flatness is evident. Lithologically, it represents the Late Jurassic carbonates of the Lagonaki Highland. Two other clasts are smaller in size. One of them lying in the midst of the roadcut slope is less than $1 \mathrm{~m}$ in diameter, which means this is a boulder, irrespective of the chosen classification. Another clast lying at the toe of the slope is up to $1.3 \mathrm{~m}$ in size, and this is either a large boulder $[1,2,4]$ or a megaclast (block) [3]. The former has a circular shape, and the other is irregular. Both are made of carbonates (with massive calcite veins in one clast).

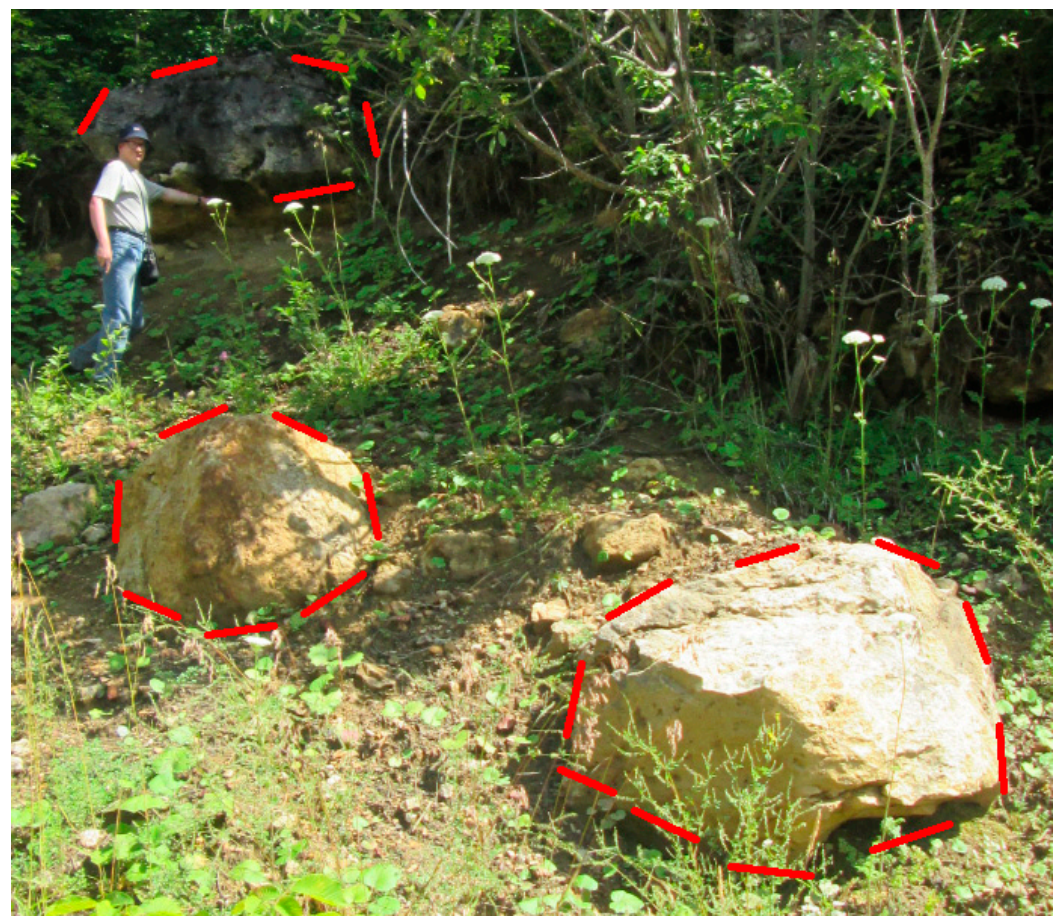

Figure 3. Large clasts (marked by red dashed line) of the Locality 2. A person is present for scale. 
The studied large clasts are not only impressive in size, but also unusual with regard to their origin. On the one hand, these should be unequivocally related to the Late Jurassic carbonates of the Stonesea Range. This typical cuesta-type range is characterized by active cliff collapses and subsequent retreat, which produce a significant number of large clasts moving down the talus slope (Figure 4). On the other hand, the analyzed large clasts occur quite far (up to $2 \mathrm{~km}$ ) from the cliff. In one case, the observed rockfall deposits spread far from the Stonesea Range. These accumulate at the toe of the cliffed slope. Moreover, modern transportation of such large clasts over such a distance (because of gravity or any other force) is improbable because of topographic barriers and dense vegetation cover.

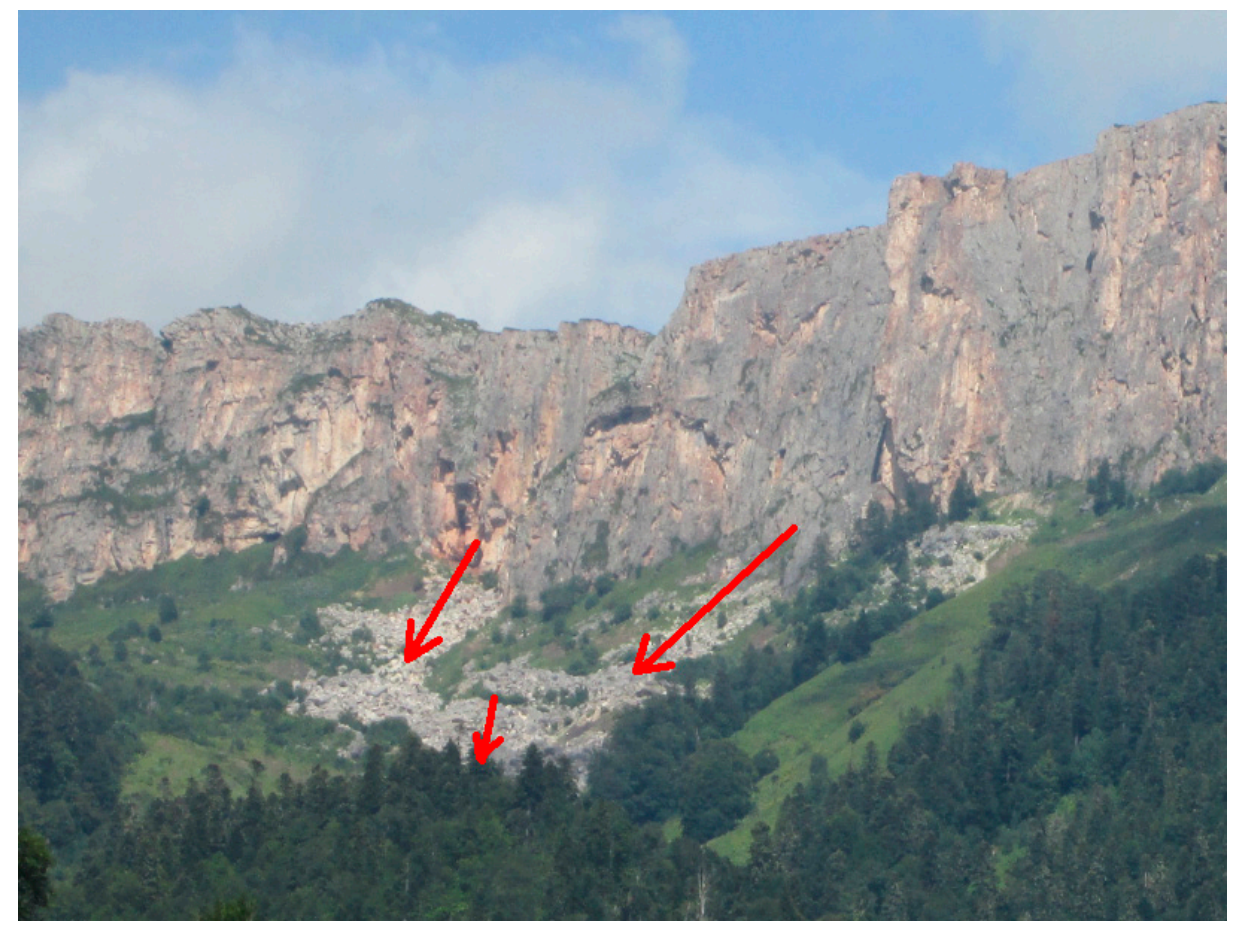

Figure 4. Colluvial deposits at the toe of the cuesta cliff of the Stonesea Range. Arrows indicate directions of clast transport.

\section{Discussion}

The present report of large clasts from the periphery of the Lagonaki Highland poses serious challenge for the size-grade classification. As noted above, different developments [1-4] make possible the attribution of these clasts to the different size grades, i.e., either to boulders or megaclasts. However, it should be noted that the studied clasts exceed in size many other clasts formed as a result of cliff collapses of the Stonesea Range. The former represents a transition between boulders and meglaclasts, whereas the latter are chiefly typical boulders. In such a case, it appears very sensible to define all analyzed large clasts as megaclasts following the lowest criterion $(1 \mathrm{~m})$ for the boulder/megaclast boundary suggested by Bruno and Ruban [3]. Of course, this can be done tentatively and in the only for the practical purposes of the present study, and further discussion of this criterion is necessary.

The origin of the studied large clasts can be interpreted as follows. The Stonesea Range represents the very edge of the Lagonaki Highland dominated by Late Jurassic carbonates. This cuesta permanently retreats because of two forces. On the one hand, numerous small tributaries of the rivers of the Belaja River Watershed, from which the Armjanka and Zhelobnaja rivers are the main, actively erode the inclined layers of carbonates and the underlying folded shales. As a result, carbonate packages exposed at the cliff lose stability and crash down. On the other hand, the Lagonaki Highland and, particularly, the Stonesea Range are known by active karstification in conditions of significant rainfall [10]. The presence of joints in limestones and dolostones allows active development of grikes, as a result of which, large blocks of carbonates separate from one another at the top of the 
Seastone Range. These regularly fall and slide down the slope (Figure 4). Smoothened surfaces and rounded angles visible in megaclasts represent karstification features, whereas certain flatness and rectangularity of clasts indicate on their separation along joint-controlled grikes. These processes have been permanent during the orogenic growth of the Western Caucasus that started in the Pliocene or even earlier. If so, it is clear that the edge of the cuesta-type range was located far from its position in the geological past, and therefore, the large clasts considered in this study can be remnants of a palaeocliff (Figure 5). These were accumulated at the toe of the ancient slope, which later retreated. This mechanism allows for an explanation of the presence of large clasts far from the modern cliff and does not require involvement of forces for their modern, long-distance transportation. Most probably, smaller boulders and lesser-size particles also accumulated, but these were later removed together with the active erosion of the exposed shale packages. Large clasts remained on place because of their huge weight, although these could slide a bit by the surface of the underlying soft shales.

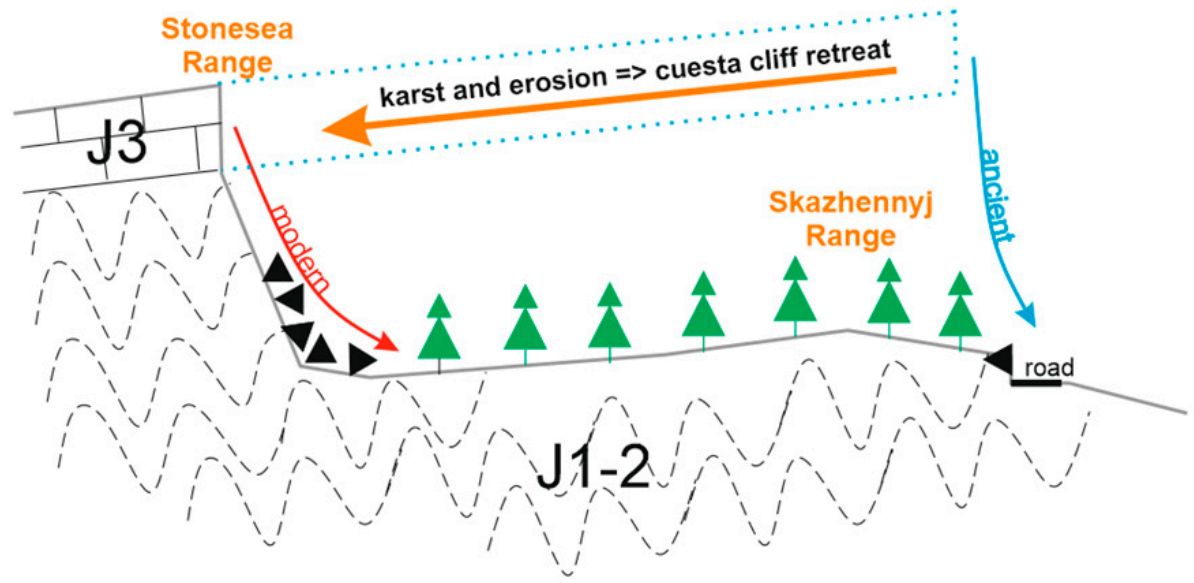

Figure 5. Conceptual explanation of the origin of the studied large clasts.

The genetic interpretation proposed above permits two interesting inferences. First, two types of colluvial megaclasts can be recognized locally, namely modern rockfall-related megaclasts and ancient rockfall-related, soil-covered, and slightly slid megaclasts. Second, the age of the studied large clasts appears to be significant. Cuesta cliff shift to its present position $(\approx 2 \mathrm{~km})$ could take thousands of years, and, most probably, the age of the large clasts is Late Pleistocene (at least). This highly hypothetic proposition corresponds well to the clast cover by mature soils. It should be added that karstification and the related cliff retreat could be much faster in the Late Pleistocene because of the glaciokarst phenomenon [15] and active denudation of topographic highs by meltwater from local glaciers developed on the Lagonaki Highland.

The new evidence from the periphery of the Lagonaki Highland appears to be valuable to some very general discussions. First, the issue of a well-accepted megaclast definition has to be addressed. As suggested by the present case study, it is sensible (for practical reasons) to think about the lower position of the boundary between boulder and megaclast grades. This may be either $1 \mathrm{~m}$ as proposed by Bruno and Ruban [3] or $2 \mathrm{~m}$ as proposed by Blott and Pye [2]. The argument that the criterion of $4 \mathrm{~m}[1,4]$ is necessary to follow the general principle of the Udden-Wenthworth classification of particles is sensible, but it is similarly important that some other reasons for placing this grade boundary may matter for large clasts. For instance, on the study area, these are the isolated clasts $>1 \mathrm{~m}$ that mark position of the cuesta palaeocliff. Second, the present evidence demonstrates that the types of megaclasts other than those of coastal zones can be of interest as markers of highly-complex and somewhat unusual geological processes. For instance, this can mark collapses of ancient slopes that were no less catastrophic than tsunamis or storms emplacing megaclasts on sea shores. 


\section{Conclusions}

The undertaken investigation of large clasts in the Western Caucasus permits making two general conclusions. First, isolated large clasts of the Skazhennyj Range can be classified either as large boulders or megaclasts (blocks) depending on the preferred classification scheme. Second, these clasts consisting of Late Jurassic carbonates were formed as a result of slope collapses of the ancient cuesta cliff, which later retreated to its present position.

Undoubtedly, further research should be aimed at the precise dating of large megaclasts of the Skazhennyj Range. More generally, improvements in the large clast classification by size and their genetic typology (and avoiding overemphasis on coastal megaclasts) are required.

Funding: This research received no external funding.

Acknowledgments: The author gratefully thanks the journal editors and the both, anonymous reviewers for their support and suggestions, as well as M.E. Johnson (USA) for various discussions and N.V. Ruban (Russia) for field support.

Conflicts of Interest: The author declares no conflict of interest.

\section{References}

1. Blair, T.C.; McPherson, J.G. Grain-size and textural classification of coarse sedimentary particles. J. Sediment. Res. 1999, 69, 6-19. [CrossRef]

2. Blott, S.J.; Pye, K. Particle size scales and classification of sediment types based on particle size distributions: Review and recommended procedures. Sedimentology 2012, 59, 2071-2096. [CrossRef]

3. Bruno, D.E.; Ruban, D.A. Something more than boulders: A geological comment on the nomenclature of megaclasts on extraterrestrial bodies. Planet. Space Sci. 2017, 135, 37-42. [CrossRef]

4. Terry, J.P.; Goff, J. Megaclasts: Proposed revised nomenclature at the coarse end of the Udden-Wentworth grain-size scale for sedimentary particles. J. Sediment. Res. 2014, 84, 192-197. [CrossRef]

5. Barbano, M.S.; Pirrotta, C.; Gerardi, F. Large boulders along the south-eastern Ionian coast of Sicily: Storm or tsunami deposits? Mar. Geol. 2010, 275, 140-154. [CrossRef]

6. Dewey, J.F.; Ryan, P.D. Storm, rogue wave, or tsunami origin for megaclast deposits in western Ireland and North Island, New Zealand? Proc. Natl. Acad. Sci. USA 2017, 114, E10639-E10647. [CrossRef] [PubMed]

7. Johnson, M.E.; Ledesma-Vázquez, J.; Guardado-France, R. Coastal Geomorphology of a Holocene Hurricane Deposit on a Pleistocene Marine Terrace from Isla Carmen (Baja California Sur, Mexico). J. Mar. Sci. Eng. 2018, 6, 108. [CrossRef]

8. Scheffers, S.R.; Scheffers, A.; Kelletat, D.; Bryant, E.A. The Holocene paleo-tsunami history of West Australia. Earth Planet. Sci. Lett. 2008, 270, 137-146. [CrossRef]

9. Lubova, K.A.; Zayats, P.P.; Ruban, D.A.; Tiess, G. Megaclasts in geoconservation: Sedimentological questions, anthropogenic influence, and geotourism potential. Geologos 2013, 19, 321-335. [CrossRef]

10. Lozovoj, S.P. Lagonakskoe Nagor'e; Krasnodarskoe knizhnoe izdatel'stvo: Krasnodar, Russia, 1984; pp. 1-160. (In Russian)

11. Adamia, S.; Alania, V.; Chabukiani, A.; Kutelia, Z.; Sadradze, N. Great Caucasus (Cavcasioni): A Long-lived North-Tethyan Back-Arc Basin. Turk. J. Earth Sci. 2011, 20, 611-628.

12. Saintot, A.; Brunet, M.-F.; Yakovlev, F.; Sébrier, M.; Stephenson, R.; Ershov, A.; Chalot-Prat, F.; McCann, T. The Mesozoic-Cenozoic tectonic evolution of the Greater Caucasus. Geol. Soc. Lond. Mem. 2006, 32, 277-289. [CrossRef]

13. Rolland, Y. Caucasus collisional history: Review of data from East Anatolia to West Iran. Gondwana Res. 2017, 49, 130-136. [CrossRef]

14. Rostovtsev, K.O.; Agaev, V.B.; Azarian, N.R.; Babaev, R.G.; Besnosov, N.V.; Hassanov, N.A.; Zesashvili, V.I.; Lomize, M.G.; Paitschadze, T.A.; Panov, D.I.; et al. Yura Kavkaza; Nauka: St. Petersburg, Russia, 1992; pp. 1-192. (In Russian)

15. Veress, M.; Telbisz, T.; Tóth, G.; Lóczy, D.; Ruban, D.A.; Gutak, J.M. Glaciokarsts; Springer: Cham, Switzerland, 2019; pp. 1-516. 
16. Blott, S.J.; Pye, K. Particle shape: A review and new methods of characterization and classification. Sedimentology 2008, 55, 31-63. [CrossRef]

17. Ruban, D.A.; Nielsen, J.K.; Mikhailenko, A.V.; Nazarenko, O.V.; Zayats, P.P. Ichnogeneric diversity in the Jurassic deposits of the Western Caucasus: A brief summary. Stratigr. Sedimentol. Oil-Gas Basins 2017, 1, 3-10. 